\title{
HYDROGEOCHEMISTRY AND QUALITY ASSESSMENT OF SOME GROUND WATER SAMPLES FROM ENUGU AND ENVIRONS, SOUTH-EASTERN, NIGERIA
}

VICTOR O. ANIEBONE

(Received 9 April 2014; Revision Accepted 29 July 2014)

\begin{abstract}
This study was carried out to evaluate the groundwater quality and its suitability for drinking purposes in Enugu and environs, southeastern Nigeria. Water samples for this study were collected from ten different locations within the study area. Nine of the samples were subjected to physico-chemical analyses only, two out of the nine were subjected to both physico-chemical and microbiological analyses, while one (Egede borehole) was subjected to microbiological analyses only. The minimum and maximum values of $\mathrm{pH}$ (4.10-7.30 on scale), turbidity (0.17-218.60 NTU), colour (5.00-250.00 Hazen), electrical conductivity $(14.00-550.00 \mu \mathrm{S} / \mathrm{cm})$, total hardness $(4.00-131.00 \mathrm{mg} / \mathrm{l})$, total iron as $\mathrm{Fe}$ $(0.12-8.60 \mathrm{mg} / \mathrm{l})$, nitrate $(0.01-3.50 \mathrm{mg} / \mathrm{l})$, sulphate $(0.50-43.00 \mathrm{mg} / \mathrm{l})$, chloride $(2.13-31.00 \mathrm{mg} / \mathrm{l})$ and temperature $\left(28-29{ }^{\circ} \mathrm{C}\right)$ were recorded in the groundwater samples from the study area Major ion concentrations were low and within the WHO guidelines for drinking water indicating chemical suitability of surface water. All the three groundwater samples tested positive to total bacterial count and $\mathrm{E}$ - coli. and this is evidence of faecal contamination and should be treated/disinfected before consumption.
\end{abstract}

KEYWORDS: Hydro-geochemistry, Groundwater Quality Assessment, Enugu and Environs, Nigeria.

\section{INTRODUCTION}

Groundwater is the major source of water supply for drinking and domestic purposes in urban as well as rural parts. Groundwater contamination is one of the most important environmental issues in the recent world (Vodela et al.1997). Groundwater quality depends on the quality of recharged water, atmospheric precipitation, inland surface water and on subsurface geochemical processes. Temporal changes in the origin and constitution of the recharged water, hydrologic and human factors may cause periodic changes in groundwater quality. The concentrations of naturally occurring chemicals such as chloride, iron, manganese, sodium, etc. does not alter public health at certain levels, but may affect the acceptability of drinking water. Groundwater is an important source of water supply in Enugu and environs. The groundwater from the underlying Ajali Sandstone aquifers provides water for both domestic, municipal and irrigation uses. The people of Enugu states have suffered a lot in terms of getting water for domestic uses. In some communities people used to trek many kilometers to fetch water. Borehole waters are quite recent in some of these communities. Chemical reactions such as weathering, dissolution, precipitation and other related processes commonly take place below the surface. The quality of groundwater at any point below the earth's surface reflects the combined effects of many processes along the groundwater flow path. The poor quality of water may lead to leaching of nutrient and release of metals from soil. The determination of groundwater quality is important to observe the suitability of water for a particular use. Geochemical studies of groundwater provide a better understanding of possible changes in quality as development progresses. There are clear incidences of pollution in the subsurface waters of the study area. The study area is affected by pollutant matters which enter ground water. The results of hydro geochemical analysis of the ground water sources lend credence to this view. The high concentration of iron of range 0.12 to $8.60 \mathrm{mg} / \mathrm{L}$ for ground water is above the maximum permissible level of water for domestic use (WHO, 1997). Waters adversely affected by abnormal concentration of iron tend to be brownish in colour. Acid mine drainage is an important form of environmental degradation in Enugu (Egboka and Uma, 1985). About 18.1 million litres of acid mine water are pumped out daily from the coal mines into the Ekulu River with the attendant potentials for pollution (Ugwu, 1984). Ground water emerging from abandoned mines and soil water percolating through stripe mines spoil banks and is charged with tetraoxosulphate (vi) acid $\left(\mathrm{H}_{2} \mathrm{~S}\right.$ 04) and other salts and metals especially iron. In view of these, there is an urgent need to evaluate the groundwater and its suitability for drinking purposes. The present study was carried out to assess the groundwater quality and its suitability for drinking purposes in Enugu and environs, southeastern, Nigeria.

\section{Study Area}

The study area is in the humid tropics lying within latitudes $5^{\circ} 56^{\prime} 42^{\prime \prime} \mathrm{N}$ to $6^{\circ} 27^{\prime} 3.6^{\prime \prime} \mathrm{N}$ and longitudes $7^{\circ}$ i $30^{\prime \prime} \mathrm{E}$ to $7^{0} 43^{\prime} 4.6^{\prime \prime} \mathrm{E}$. The study area comprises Enugu the state capital and areas like Ezeagu, Udi, Nkanu, Oji River and some parts of Awgu and Aninri local

Victor O. Aniebone, Marine geology and geophysics Department, Nigerian Institute for Oceanography and Marine Research, Lagos State, Nigeria. Nigeria 
government areas of Enugu state. The area has high amounts of rainfall and high temperatures throughout the year. The mean annual rainfall falls within the range of $1750-1890 \mathrm{~mm}$. The distribution is bimodal with peaks in July and September. The mean annual temperature range is $21-29^{\circ} \mathrm{C}$. Relative humidity does not fall below $60 \%$ except during the period of harmattan, a short period in the dry season during which the atmosphere is very dry and hazy usually in December to early January. The topography of the area is a reflection of the tectonic and geologic events that occurred over the years and mildly neo-tectonically continues today to shape the geomorphic landscape, (Egboka et al. 1989). The landforms are categorized into cuestas, plains and lowland landscapes.

\section{GEOLOGY AND HYDROGEOLOGY OF THE STUDY AREA}

The geology of study area can be broadly classified into shales, False-bedded Sandstones and Coal Measures (Akamigbo, 1987). The geologic map of Enugu State is shown in figure 1. The formations encountered in the study area are the Imo Shale, Nsukka Formation, Ajali Sandstone, Mamu Formation and Enugu Shale. Others are Nkporo Shales, Awgu Shale, Eze-Aku Shale and Asu River Group(Abakaliki Shale. The Ajali, Mamu and Nsukka Formations Furnish the Study area with water. These formations are highly aquiferous. The area is drained by many rivers/streams flowing dendritically towards the major rivers. The rivers include Ekulu, Nyaba, Ajali, Oji, Atafo, Mamu, Asu, lyoko, Idodo, and
Nnam. Others are Adada, Awra, Aiddo, Iva, Karawa e.t.c. The presence of a north-south trending cuesta or escarpment that crosses the study area form the recharge and discharge area and creates major surface and ground water divides for the two great drainage basins of Cross River and Anambra, east and west respectively. Some of the major rivers flow eastwards into the Cross River Basin while the rest flow westwards into Ajali and Mamu rivers and later into the Anambra River Basins. This indicates possible existence of water divide along the axis of the Enugu escarpment. The Ajali, Mamu and Nsukka Formations furnish the study area with water. The multi-aquifer system is found in Ajali Sandstone and Mamu Formation. The Ajali Sandstone is highly aquiferous, the Mamu is fairly aquiferous contributing inflows of acidic and iron-rich water into the coal mines. The Nsukka sandy shales are poorly aquiferous and may act as aquitards while fractured Nsukka sandstones are also aquiferous. The Mamu aquifers are separated by fractured aquitards in form of siltstone or shale. The Mamu sand and coal aquifers vary in thickness ranges from about 3.0 to $30.0 \mathrm{~m}$ and 1.0 and $1.5 \mathrm{~m}$ respectively (Nwankwor et al, 1988) and aquitard thickness range from about0.5 to $1.0 \mathrm{~m}$. The unconfined Ajali aquifers have a range of thickness of about 25.0 to $850 \mathrm{~m}$. The grain size is medium to coarse grained but becomes fine to silty and finally grades into shale and coal units at the base or contact with the Mamu Formation. The aquifer parameters for Ajali, Nsukka and Mamu aquifers indicate that they are of good performance. 


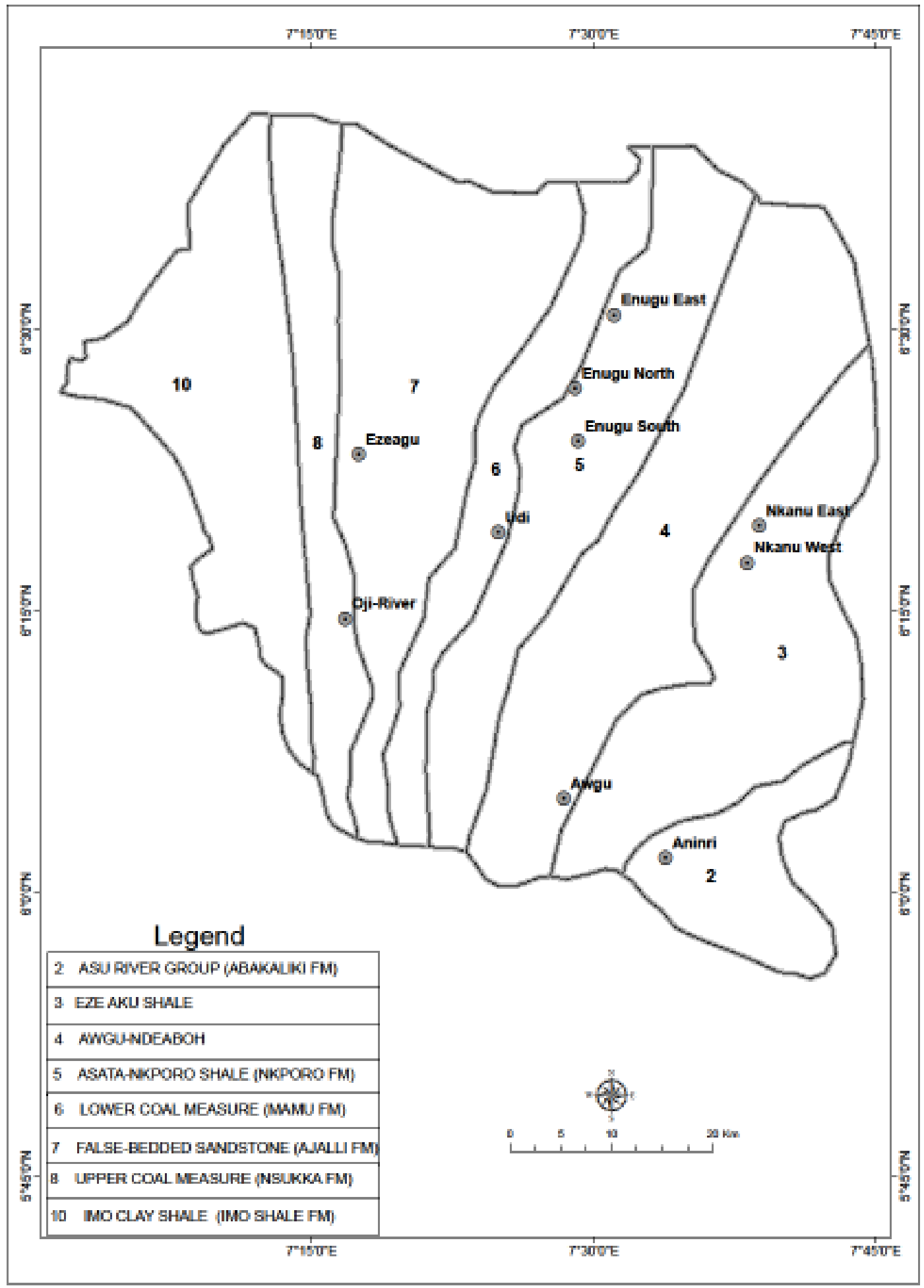

FIG.1 LOCATION AND GEOLOGIC MAP OF THE STUDY AREA(SOURCE:ANAMBRA STATE TASK FORCE ON SOIL EROSION CONTROL, 1987)

\section{METHOD OF STUDY}

Water samples for this study were collected from ten different locations within the study area (Figure 1). Nine of the samples were subjected to physico-chemical analyses only, two out of the nine were subjected to both physic-chemical and microbiological analyses, while one (Egede borehole) was subjected to microbiological analyses only. The water samples were analysed for $\mathrm{pH}$, turbidity, colour, electrical conductivity, total hardness, silica, total iron, nitrate, sulphate, sodium, chloride, alkalinity, and temperature. The 
groundwater samples were collected in high density polyethylene bottles prewashed with $1 \mathrm{~N}$ hydrochloric acid followed by distilled water and then rinsed two to three times before sampling using sampling water. The collected samples were transferred to a laboratory for further analysis and kept at $5{ }^{\circ} \mathrm{C}$. The samples were filtered using $0.45 \mu \mathrm{m}$ cellulose membrane before the analysis. The temperature of the groundwater samples was determined using a common mercury thermometer. The $\mathrm{pH}$ values of all the samples were determined directly at the sources and also by using the unacidified portions in the laboratory. Turbidity was measured with a HACP 400P.turbidimeter, Chloride concentration was measured by $\mathrm{AgNO}_{3}$ titration method and sulphate was determined by $\mathrm{BaCl}$ (turbidity techniques) method using a spectrophotometer. Hardness was analyzed by titration with EDTA. The metal iron was analyzed by AAS technique. The microbial analyses consisted of colony generation and Membrane Filtration. The microbial qualities were determined using the membrane filtration technique and "CHECK WATER" BACTO H2S TEST KIT, (Bacteriological) Field Test Kit for drinking water. The analytical procedures are as suggested by the American Public Health Association (APHA 1995).

\section{STATISTICAL ANALYSIS OF DATA}

Simple statistical technigue such as mean, analysis of variance (ANOVA) was used in this study.

\section{RESULTS AND DISCUSSION}

Maximum, minimum, mean and their standard deviation values of the analyzed variables of groundwater samples $(n=10)$ and drinking water standards (World Health Organization 2011) are summarized in Table 1, while the results of the microbiological analyses of the ground water samples $(n=3)$ are shown Table 2 below.

TABLE 1: HYDROGEOCHEMICAL ANALYSIS RESULT OF SOME GROUNDWATER SAMPLES

\begin{tabular}{|c|c|c|c|c|c|c|c|c|c|c|c|c|c|c|}
\hline $\begin{array}{l}\text { Geochemical } \\
\text { Parameters }\end{array}$ & $\begin{array}{l}\text { G/Wate } \\
\text { r } \\
\text { From } \\
\text { Udi }\end{array}$ & $\begin{array}{l}\text { G/Water } \\
\text { From 9th } \\
\text { Mile } \\
\text { corner }\end{array}$ & $\begin{array}{l}\text { Onyeam } \\
\text { a } \\
\text { Mine } \\
\text { Water }\end{array}$ & $\begin{array}{l}\text { Iva } \\
\text { Mine } \\
\text { Water }\end{array}$ & $\begin{array}{l}\text { G/Wate } \\
\mathbf{r} \\
\text { From } \\
\text { Oghe }\end{array}$ & $\begin{array}{l}\text { G/Wate } \\
r \text { from } \\
\text { Awkun } \\
\text { anaw }\end{array}$ & $\begin{array}{l}\text { G/Wate } \\
r \text { from } \\
\text { Affa }\end{array}$ & $\begin{array}{l}\text { G/Wate } \\
\mathbf{r} \text { from } \\
\text { Eke }\end{array}$ & $\begin{array}{l}\text { G/Water } \\
\text { from } \\
\text { Agbogug } \\
\text { u }\end{array}$ & $\begin{array}{l}\text { G/Wat } \\
\text { er } \\
\text { from } \\
\text { Nachi }\end{array}$ & Min & Max & Mean & $\begin{array}{l}\text { Standar } \\
\text { d } \\
\text { Deviatio } \\
\mathrm{n}\end{array}$ \\
\hline $\mathrm{pH}$ & 7.00 & 6.41 & 4.10 & 6.30 & 6.90 & 6.61 & 6.73 & 5.80 & 7.06 & 7.30 & 4.10 & 7.30 & 6.42 & 0.88 \\
\hline Turbidity & 60.00 & 0.17 & 106.00 & $\begin{array}{l}116.9 \\
0\end{array}$ & 218.60 & 115.60 & 119.60 & 0.35 & 18.00 & 1.02 & 0.17 & $\begin{array}{l}218.6 \\
0\end{array}$ & 75.62 & 68.62 \\
\hline $\begin{array}{l}\text { Colour(Haze } \\
\text { n Units }\end{array}$ & 150.00 & 5.00 & 250.00 & 50.00 & 47.00 & 50.00 & 100.00 & 5.00 & 5.00 & 50.00 & 5.00 & $\begin{array}{l}250.0 \\
0\end{array}$ & 71.00 & 73.55 \\
\hline $\begin{array}{l}\text { Electr. } \\
\text { Conduct. } \\
(\mu \mathrm{S} / \mathrm{cm})\end{array}$ & 80.00 & 25.00 & 150.00 & 72.00 & 70.00 & 30.00 & 14.50 & ND & 550.00 & 14.00 & $\begin{array}{l}14.0 \\
0\end{array}$ & $\begin{array}{l}550.0 \\
0\end{array}$ & $\begin{array}{l}111.7 \\
2\end{array}$ & 160.24 \\
\hline $\begin{array}{l}\text { Total } \\
\text { hardness(m } \\
\text { g/L) }\end{array}$ & 20.02 & 11.00 & $38 .-00$ & 27.60 & 67.98 & 131.00 & 4.00 & 4.00 & 30.00 & 6.00 & 4.00 & $\begin{array}{l}131.0 \\
0\end{array}$ & 33.96 & 37.34 \\
\hline $\begin{array}{l}\text { Silica as } \\
\text { Sio2(mg/L) }\end{array}$ & 20.00 & 16.00 & 30.00 & 10.00 & 25.00 & 9.00 & 16.00 & 28.00 & 20.00 & 16.00 & 9.00 & 30.00 & 19.00 & 6.69 \\
\hline $\begin{array}{l}\text { Total Iron as } \\
\text { Fe (mg/L) }\end{array}$ & 1.45 & 0.20 & 1.41 & 8.60 & 1.81 & 7.11 & 1.28 & 0.12 & 1.40 & 1.00 & 0.12 & 8.60 & 2.44 & 2.78 \\
\hline $\begin{array}{l}\text { Nitrate } \\
\text { (mg/L) }\end{array}$ & 1.25 & 3.50 & 0.01 & 0.25 & 0.59 & 0.26 & ND & ND & ND & 0.08 & 0.01 & 3.50 & 0.85 & 1.15 \\
\hline $\begin{array}{l}\text { Sulphate(mg } \\
\text { /L) }\end{array}$ & 0.74 & 3.89 & 43.00 & 27.60 & 1.00 & 0.50 & ND & ND & 12.00 & 10.00 & 0.50 & 43.00 & 12.34 & 14.38 \\
\hline $\begin{array}{l}\text { Chloride as } \\
\text { CL (mg/L) }\end{array}$ & 31.00 & 3.16 & 2.19 & 2.13 & 3.01 & 7.00 & 2.48 & 4.30 & 8.51 & 5.50 & 2.13 & 31.00 & 6.93 & 8.28 \\
\hline $\begin{array}{l}\text { Temperature } \\
{ }^{0} \mathrm{C}\end{array}$ & 29 & 28 & 29 & 28 & 28 & 29 & 28 & 28 & 29 & 29 & 28 & 29 & 28.5 & 0.5 \\
\hline
\end{tabular}


TABLE 2: BACTERIALOGICAL ANALYSIS RESULT OF SOME GROUNDWATER SAMPLES

\begin{tabular}{|c|c|c|c|c|}
\hline $\begin{array}{l}\text { SOURCE } \\
\text { WATER }\end{array}$ & $\begin{array}{l}\text { COLI FORM } \\
\text { MPN/100ML }\end{array}$ & $\begin{array}{l}\text { E-COLI POSITIVE } \\
\text { OR } \\
\text { NEGATIVE }\end{array}$ & $\begin{array}{l}\text { PLATE COUNT } \\
\text { COLONIES }\end{array}$ & REMARKS \\
\hline $\begin{array}{l}\text { Ninth Mile Corner } \\
\text { Boreholes: } \\
\text { Untreated }\end{array}$ & 70 & Positive & $\begin{array}{l}4 \text { colonies after } \\
24 \mathrm{hrs} \text { at } 37^{0 \mathrm{c}}\end{array}$ & Suspicious \\
\hline $\begin{array}{l}\text { Udi water supply } \\
\text { Untreated } \\
\text { borehole }\end{array}$ & 3 & Positive & $\begin{array}{l}3 \text { colonies after } \\
24 \mathrm{hrs} \text { at } 37^{0 \mathrm{c}}\end{array}$ & Suspicious \\
\hline $\begin{array}{l}\text { Borehole at } \\
\text { Egede: } \\
\text { Untreated }\end{array}$ & 50 & Positive & $\begin{array}{l}4 \text { colonies after } \\
24 \mathrm{hrs} \text { at } 37^{0 \mathrm{c}}\end{array}$ & Suspicious \\
\hline
\end{tabular}

\section{RESULTS OF THE HYDROGEOCHEMICAL ANALYSES}

The hydrogen ion concentration $(\mathrm{pH})$ of ground water samples varied from 4.10 to 7.30 with a mean value of 6.42 . The lowest $\mathrm{pH}$ value of 4.10 was recorded at Onyeama mine water and this can be attributed to the high acid content of the mine water discharges. The rest of the water samples can be considered suitable for drinking and other domestic purposes. The turbidity of the ground water samples varied from 0.17 to 218.60 NTU with a mean value of 75.62 NTU. Out of the 10 ground water samples only 3 sites were within WHO $(<5)$ standard while the rest were high.

The colour of the groundwater sample varied from 5 to 250 Hazen with a mean value of 71 Hazen. The lowest values of 5 Hazen were recorded at the groundwater samples from Ninth Mile corner, Eke and Agbogugu while the highest value of 250 Hazen was recorded at the groundwater sample from Onyeama mine.

Electrical conductivity $(E C)$ is an indicator of the presence of ions and concentrations of dissolved components and has a direct relationship with salinity and TDS which are used for groundwater classification. The EC ranges from 14 to $550 \mu \mathrm{S} / \mathrm{cm}$. Groundwater was reclassified using a TDS (after Todd 1980) into very fresh $(0-250 \mathrm{mg} / \mathrm{L})$, fresh $(250-1,000 \mathrm{mg} / \mathrm{L})$, brackish $(1,000-10,000 \mathrm{mg} / \mathrm{L})$ and saline $(10,000-100,000 \mathrm{mg} / \mathrm{L})$. Using this categorization, therefore, 9 out 10 groundwater samples qualifies as very fresh, while only one sample the groundwater from Agbogugu qualifies as fresh. It means that all the ground water samples are suitable for drinking and other domestic uses.

The calculated total hardness of the water samples varied from 4.00 to $131.00 \mathrm{mg} / \mathrm{L}$ with the mean value of $33.96 \mathrm{mg} / \mathrm{L}$ (Table 1).On the basis of total hardness water can be classified as $\operatorname{soft}(<75 \mathrm{mg} / \mathrm{L})$, moderately hard $(75-150 \mathrm{mg} / \mathrm{L})$, hard $(150-300 \mathrm{mg} / \mathrm{L})$, and very hard $(>300 \mathrm{mg} / \mathrm{L})$ (Sawyer and McCarty, 1967). According to the criteria above out of 10 water samples 9 samples were graded as soft while only 1 sample at Awkunanaw where the value is $131.00 \mathrm{mg} / \mathrm{L}$ was graded as moderately hard. It implied that out of the 10 water sample 9 were suitable for drinking while 1 was found unsuitable for drinking. The high value implies that Awkunanaw area is characterized by hard water and this may be due to limestone lenses or outcrop in the Imo
Shale Formation. Here, the water needs to be treated before it reaches the standard for human consumption and other domestic uses.

Chloride occurs naturally in all types of water. The amount of chloride content in the ground water samples was recorded from 2.13 to $31 \mathrm{mg} / \mathrm{L}$ with a mean value of $6.93 \mathrm{mg} / \mathrm{L}$. Weathering and dissolution of salt deposits, seawater intrusion and irrigation return flow are commonly responsible for the increasing chloride content in the groundwater (Jeevanandam et al. 2012). According to Walker et al. (1991), Cl ion concentration in the groundwater normally arises from sources like paleoseawater entrapped sediments, solubility of $\mathrm{Cl}$-bearing evaporation deposits and from anthropogenic sources. The concentration is generally low because of the fact that chloride does not show any correlation with the components of pore water derived from mineral breakdown (Spears and Reeves, 1975) and because of the fact sedimentary rocks the major source of chloride in ground water is due to evaporate (Hem, 1970). Another source of chloride in ground water is the leaching of chloride from fine grained marine shales which might retain some chloride for a long time. These values are very low and implies also that the ground water in the study area are free from faecal pollution. In regard to chloride, all water samples under investigation were found suitable for drinking.

The iron content of the ground water ranges from 0.12 to $8.60 \mathrm{mg} / \mathrm{L}$ with a mean value of $2.44 \mathrm{mg} / \mathrm{L}$ (Table 1).Maximum recommended concentration of $\mathrm{Fe}$ used for drinking is $0.3 \mathrm{mg} / \mathrm{L}(\mathrm{WHO}$, 1997). Considering these values as standard only two groundwater samples, Ninth Mile corner and Eke were suitable for drinking the rest were above both the WHO's highest desirable level as well as the maximum permissible level. These high values imply that adequate treatment should be given to water against the abnormal concentration of iron before the water is supplied.

The concentration of nitrate does not exceed $10 \mathrm{mg} / \mathrm{L}$ in water under natural conditions (Cushing et al. 1973). The nitrate concentration varies from 0.01 to $3.5 \mathrm{mg} / \mathrm{L}$ with a mean value of $0.85 \mathrm{mg} / \mathrm{L}$. The concentration of nitrate is within the WHO-suggested permissible limit $(45 \mathrm{mg} / \mathrm{L})$. Ammonium is transferred to nitrate by the nitrification process in the presence of oxygen The possible sources of nitrates are poultry farms, animal wastages and septic tank leakages in the urban area and probably the atmosphere. Nitrate leaching is 
enhanced by high infiltration of soil layer and low runoff potential. The presence of high nitrate concentration in the drinking water increases the incidence of gastric cancer and other potential hazards to infants and pregnant women (Nagireddi Srinivasa Rao 2006).

The sulphate concentration ranges from 0.50 to $43 \mathrm{mg} / \mathrm{L}$, with a mean value of $12.34 \mathrm{mg} / \mathrm{L}$ (Table 1 ). The concentration of sulphate is within the maximum permissible limit of WHO standard $(200 \mathrm{mg} / \mathrm{L})$. All the groundwater samples under investigation area were suitable for drinking usage in respect to sulphate content. The major source of sulphate in the area may from gypsum and oxidation of sulphide ores. $29^{\circ} \mathrm{C}$

The groundwater temperature ranges from 28 to

\section{RESULT OF BACTERIAL COUNT AND E-COLI TEST}

All the three groundwater samples for microbiological analysis gave positive result to total bacterial count and $\mathrm{E}$ - coli test. The positive result implies that the water has faecal contamination and most likely has hazardous effect and therefore are suspicious and not suitable for drinking and domestic purposes (Table 2). The water therefore, should be subjected to adequate treatment before being supplied.

\section{CONCLUSION}

In this study, 10 groundwater samples were collected, analyzed and assessed for drinking water quality. The $\mathrm{pH}$ value of the groundwater was very acidic in area like Onyeama mine ( $\mathrm{pH}$ value 4.10 ), slightly acidic in few sites and within the WHO acceptable limit in most places. Based on EC classification, the groundwater sample is very fresh to fresh in nature. Geochemical parameters such as $\mathrm{Cl}^{-}, \mathrm{SO}_{4}{ }^{2-}$, and $\mathrm{NO}_{3}$ show good correlation with positive factor loadings. There are clear incidences of pollution in some and not all subsurface waters of the study area. The quality of the groundwater in the study area is impaired by seawater intrusion and rock-water interaction processes. The aquifers in some places are contaminated with iron, sulphate and gypsum dissolution which may cause serious health hazards to the populated areas of the study area. The high concentration of iron of range 0.12 to $8.60 \mathrm{mg} / \mathrm{L}$ for ground water is above the maximum permissible level of water for domestic use (WHO, 1997). Waters adversely affected by abnormal concentration of iron tend to be brownish in colour. Acid mine drainage is an important form of environmental degradation in Enugu ( Egboka and Uma, 1985).Ground water emerging from abandoned mines and soil water percolating through stripe mines spoil banks and is charged with tetraoxosulphate (vi) acid $\left(\mathrm{H}_{2} \mathrm{~S}\right.$ 04) and other salts and metals especially iron. The tetraoxosulphate (vi) acid $\left(\mathrm{H}_{2} \mathrm{~S}\right.$ O4) is formed by reaction of water with iron sulphides mainly mineral pyrite $\left(\mathrm{Fe}_{2} \mathrm{~S}\right)$ which is a common constituent of coal seams. Other sources of water pollution in the suburbs of Enugu and other parts of the state include septic systems, the bucket system of toiletry, the use of bush method for defecation by rural dwellers, tremendous amount of fertilizers applications during farming and uncontrolled municipal and industrial waste/garbage disposal. This was proven by the positive test to bacterial count and E- Coli presence in the ground water samples that were subjected to microbiological analysis. Based on the hydrogeochemical investigations, WHO standards, the groundwater samples can be used for drinking after removing and reducing the concentration of those ions in high proportions in groundwater. Nevertheless, based on the WHO standard more than $80 \%$ of the groundwater samples are suitable for drinking.

\section{REFERENCES}

Akamigbo, F. O. R., 1987. Pedological and Pedogenetic Components of Soil formation and Erosion. National Workshop on soil Erosion Control, UNN.

APHA., 1995. Standard methods for the examination of water and wastewater, 19th edn. American Public Health Association, Washington, DC,

Aniebone, V. O., 1999. Geology of Obinofia Ndiuno and Environs. Unpublished PGD Thesis, Nnamdi Azikiwe University, Awka.

Cushing, E. M., Kantrowitz, I. H and Taylor, K. R., 1973. Water resources of the Delmarva Peninsular. U S Geological Survey Professional Paper 822, Washington DC

Egboka, B. C. E., 1984. Water resources of Nsukka area and the environs. Nig. J. Min. , Vol. 20, Nos. 1 and 2, pp: 1-6.

Egboka, B. C. E., 1985. Water resources problems of Enugu area, Anambra State. Nigeria JAHS Publ. , No.153, pp.95-106

Egboka, B. C. E and Uma, K. C., 1985. Acid mine drainage problem of Enugu coal mines of Anambra State Nigeria._Mine Water. , Grenada, Spain, 1, 1-11.

Egboka, B. C. E., Nwankwor, G. I and Orajaka, I. P., 1989. Implications of palaeo and neotectonics in gully erosion prone areas of Southern Nigeria. Natural Hazards J., The Netherlands (In Press).

Hem, D. J., 1970. Study and Interpretation of Chemical Characteristics of Natural Water" Paper No. 1473. US Geological Survey. Washington DC.

Jeevanandam, M., Nagarajan, R., Manikandan, M., Senthilkumar, M., Srinivasalu, S and Prasanna, M. V., 2012. Hydrogeochemistry and microbial contamination of groundwater from Lower Ponnaiyar Basin, Cuddalore District, Tamil Nadu, India. Environ Earth Sci 67, (3): 867-887.

Murat, R. C., 1972. Stratigraphy and Paleontology of the Cretaceous and Lower Tretiary in Southern Nigeria, Africa geology. Ibadan Univ. Press pp. 252-779.

Nagireddi Srinivasa Rao., 2006. Nitrate pollution and its distribution in the groundwater of Srikakulam 
district, Andhra Pradesh, India. Environ Geol 51, (4): 631-645.

Nwankwor, G. I., Egboka, B. C. E and Orajaka, I. P., 1988. Groundwater Occurrence and flow patterns in Enugu Coal mine area, Anambra State, Nigeria. Hydrol. SC. J., London, 33, (5\&10): 465-482.

Sawyer, C. N and McCarty. P. L., 1967. Chemistry Sanitary Engineers. $2^{\text {nd }}$.ed. McGraW- HILL New york

Spears, D. A and Reeves, M. J., 1975. "The Influence of Superficial Deposits on Groundwater Quality in Vale York" Q. J. Engng. Geol. (8): 225-270.

Todd, D. K., 1980. Groundwater hydrology. Wiley, New York.

Ugwu, F. N., 1984. Development of Coal Mining in Nigeria. Proceedings of the Nig. Min. Geo Sc. Soc., University of Nigeria, Nsukka, 13.
Ugwu, P. O., 1990. The Water resources of Enugu and Environs, Anambra State. Unpublished PGD Thesis, Anambra State University of Technology.

Vodela, J. K., Renden, J. A., Lenz, S. D., McElhenney, W. H and Kemppainen, B. W., 1997. Drinking water contaminants (arsenic, cadmium, lead, benzene and trichloroethylene). 1. Interaction of contaminants with nutritional status on general performance and immune function in broiler chickens. Poult Sci (76): 1474-1492.

Walker, G. R., Jolly, I. D and Cook, P. G., 1991. A new chloride leaching approach to the estimation of diffuse recharge following a change in land use. J Hydrol (128): 49-67.

WHO., 1997. International Standards for Drinking Water. World Health Organization, Geneva. 